\title{
Performance of mycelium composites of Lentinus crinitus under two compression protocols
}

\section{Comportamiento de composites miceliares de Lentinus crinitus bajo dos protocolos de compresión}

\author{
Enrique Césarl, Leticia Montoya², Guadalupe M. Bárcenas-Pazos³, \\ Víctor R. Ordóñez-Candelaria³ and Víctor M. Bandala²
}

\begin{abstract}
1 Instituto de Ecología, A.C. Herbario XAL. Xalapa, Veracruz, México.

2 Instituto de Ecología, A.C. Red Biodiversidad y Sistemática. Xalapa, Veracruz, México.
\end{abstract}

\author{
3 Instituto de Ecología, A.C. Red Ambiente y * Corresponding author. victor.bandala@inecol.mx \\ Sustentabilidad., Xalapa, Veracruz, México. (retired)
}

\begin{abstract}
ABSTRACT

Considering the current environmental problems that has been generated by the excessive production of synthetic plastics, more sustainable alternatives have been proposed. One of these recently studied materials are the mycelium composites, a product obtained with lignocellulosic particles agglomerated together by the myceliar growth of a filamentous fungus. This novel type of materials could represent an option to replace non-biodegradable materials. In this work, mycelium composites with characteristics comparable to expanded polystyrene (EPS) and potentially suitable for fabrication of insulation panels were developed using a Lentinus crinitus strain previously selected after mycelial phases tests. Mechanical variables in bending, compression strength and stiffness were measured following ASTM D143 standard. Two protocols for composite fabrication were followed using different compression loads. Flexural strength reached $0.48 \mathrm{MPa}$ and compression strength $0.235 \mathrm{MPa}$. Results obtained were compared with data of balsa wood (Ochroma pyramidale) for the similarity of possible applications, expanded polystyrene as its possible substitute and early published data on mycelium composites. Mechanical performance in flexural and compressive strength of the obtained materials revealed their potential use as biodegradable alternatives to some applications of synthetic plastics as insulation panels and packing materials.
\end{abstract}

KEYWORDS: basidiomycetes, biodegradable, compostable, lignocellulosic, plastic alternatives, pollution.

\section{RESUMEN}

Considerando la problemática actual que ha generado la producción desmedida de materiales plásticos sintetizados de hidrocarburos, se ha buscado desarrollar alternativas más sustentables. Un material alternativo que se ha estudiado recientemente, son los composites (o compuestos) miceliares, productos obtenidos de la cohesión de partículas de desechos lignocelulósicos por medio del crecimiento de una matriz miceliar de un hongo filamentoso. Dichos productos pueden presentar potencial para suplir a materiales no biodegradables. En el presente trabajo, se desarrollaron composites miceliares con características comparables al poliestireno expandido y adecuados para la fabricación de paneles aislantes, utilizando una cepa de Lentinus crinitus, la cual fue puesta a prueba previamente para determinar su utilidad para ese fin. Variables mecpanicas como la resistencia a la compresión y rigidez fueron medidas siguiendo la norma ASTM D143. Para evaluar la importancia que puede representar el prensado de los composites en su fabricación, dos protocolos fueron seguidos, utilizando dos diferentes cargas de prensado como parte del proceso de obtención del producto final. La resistencia a la flexión de los materiales puestos a prueba alcanzó $0.48 \mathrm{MPa}$ y la resistencia a la compresión $0.235 \mathrm{MPa}$. Los resultados se compararon con los obtenidos en madera balsa, por considerarse un producto natural con características semejantes en cuanto a sus aplicaciones; poliestireno expandido, como su posible sucedáneo; y datos recabados de publicaciones previas sobre composites miceliares. El comportamiento mecánico de los materiales obtenidos en este estudio ante cargas de flexión y de compresión demuestra que estos tienen viabilidad como alternativas a algunos plásticos sintéticos utilizados en aplicaciones como los paneles aislantes y materiales de embalaje.

PALABRAS ClAVE: basidiomicetos, biodegradable, compostable, lignocelulósico, plásticos alternativos, contaminación. 


\section{INTRODUCTION}

For many years the idea to replace oil-based plastics by biodegradable materials has attracted the attention of specialists and several alternatives have been promoted (Netravali, \& Chabba, 2003). One of these alternatives is materials based on fungal mycelium composites. This novel kind of agglomerates is made with lignocellulosic particles using a mycelial matrix as binder agent. Colonized particles are molded, pressed, and dried, obtaining agglomerates with a desired form (Jones, Huynh, Dekiwadia, Daver, \& John, 2017). Materials obtained are relatively light and compostable, which made them appropriate for ephemeral uses. One convenient feature in this matter is the feasibility of to take advantage of agro-industrial wastes as substrates like barley and wheat straw, cotton gin, soy husks, sugar cane bagasse or corn stover among others, that could represent a pollution problem when burned, rot in situ or threw on water bodies (Chen, Yang, \& Zhang, 2009; Chen, 2014).

Previous works show the functionality of materials based on mycelium composites as acoustic insulators, construction or packing materials, and even substitutes of leather or fabrics (Pelletier, Holt, Wanjura, Bayer, \& McIntyre, 2013; Pelletier et al., 2017; Roman-Ramos, LunaMolina, \& Bailón-Pérez, 2014; Dschida, 1997). Currently, these kinds of materials are produced in an industrial way by some companies (https://ecovativedesign.com/), also designers and architects are involved in the development of this technology and its applications (Camere \& Karana, 2018). Albeit the potential for improving this type of fungal application is important, research on this topic is still scarcely published. Some studies have evaluated properties performing tests in the materials to determine variables like compressive strength, acoustic insulation, modulus of elasticity, dimensional stability, and others (Jones et al., 2017; Tudryn, Smith, Freitag, Bucinell, \& Schadler, 2017; Yang, Zhang, Still, White, \& Amstislavski, 2017). In some cases, size and shape of the test specimens did not follow standardized specifications even when this is critical for more accurate comparisons.
A variable of importance should first be the selection of the fungal species for the mycelial matrix and the characteristics to choose them. Ganoderma lucidum and Pleurotus ostreatus have been largely used in various works for different purposes (Holt et al., 2012; López, MéndezGonzález, Ruelas, \& Nájera, 2016; Haneef et al., 2017; Jones et al., 2017; Pelletier et al., 2017). Coriolus versicolor (Lelivelt, 2015), Irpex lacteus (Yang et al., 2017) and Daedaleopsis confragosa-Ganoderma resinaceum (Bajwa, Holt, Bajwa, Duke, \& McIntyre, 2017) have also been studied. Based on the kind of hyphal systems (Corner, 1932), the selection of taxa with a trimitic hyphal composition could be adequate to create composites with stronger structure and a more resistant composition than other with dimitic or monomitic hyphal system, considering the inner features exhibited by species with such anatomy.

In a previous research, César (2018) made puncture resistance tests on some strains isolated from wild mushrooms. A strain of L. crinitus ECC16, after evaluations, was selected to develop fungal composites. The species produces a trimitic hyphal system which could be an adequate characteristic used for such purposes. Besides its hyphal characterization, $L$. crinitus is distributed worldwide, it has a steady growth on PDA medium (Petersen, Nicholl, \& Hughes, 1997; Senthilarasu, 2015) and creates mycelium matrices with a leathery texture.

The processes to manufacture mycelium composites are diverse and still improving. The compression forces to which the mycelium matrices are exposed before drying is a variable that could be important to evaluate in order to improve mechanical characteristics and is a part of the fabrication method that previous works had not mentioned explicitly. In this work, mycelial biocomposites made with barley straw and a $L$. crinitus strain were fabricated and mechanically tested following the guidelines established in ASTM D 143 specifications for Small Clear Specimens of Timber. Two different loads were used to compress the composites before drying them. Obtained materials were tested accordingly to the followed standards. 


\section{OBJECTIVES}

To determine if a pressing protocol of the composites in the fabrication process modifies the results of compressive and flexural strength obtained in mechanical tests.

\section{MATERIALS AND METHODS}

\section{Strain and spawn preparation}

The L. crinitus strain ECC16 was used to develop the mycelial matrix. The strain used was conserved in PDA medium covered with sterilized mineral oil at room temperature, and it was taxonomically identified by molecular methods (César, 2018) and kept in Laboratorio de Biodiversidad y Sistemática, Instituto de Ecología A.C. To develop a new culture from the conserved one, little portions of mycelia were taken and washed carefully in sterilized distilled water and put on PDA Petri dishes. Once the mycelium covered approx. $70 \%$ of the plate, it was transferred to liquid media. The liquid media used $(2.5 \mathrm{~g}$ saccharose, 2.5 g potato extract, $250 \mathrm{ml}$ distilled water) was sterilized and cooled following the protocol of Chang and Miles (1989). Four pieces of $0.5 \mathrm{~cm}^{2}$ of colonized agar were introduced in Erlenmeyer flasks with $250 \mathrm{ml}$ of liquid media and shook at $120 \mathrm{rpm}$ for $72 \mathrm{hrs}$. Spawn was made with sorghum grains, washed, and sterilized at $121{ }^{\circ} \mathrm{C}$ for $1.5 \mathrm{~h}$ and inoculated with liquid media (7 days of development). Once cooled, plastic bags with $250 \mathrm{~g}$ of grain were inoculated with $15 \mathrm{ml}$ of liquid media and placed in darkness seven days at $25^{\circ} \mathrm{C}$ for incubation.

\section{Substratum preparation}

Barley straw was used as substrata. Packs without fungal contamination were selected and chopped with an animal feed shredder to obtain straw pieces between $10 \mathrm{~mm}$ to 80 $\mathrm{mm}$. Straw was moistened for $12 \mathrm{~h}$, then pasteurized at 60 ${ }^{\circ} \mathrm{C}$ for $1 \mathrm{~h}$. Later it was cooled and conditioned to $70 \%$ moisture. The inoculated straw with $10 \%$ spawn was placed in transparent plastic bags, lightly compacted with the hands and incubated for seven days at $25^{\circ} \mathrm{C}$. At day eight, casts were filled with the colonized straw, cover with a plastic mat and incubated for seven days more.

\section{Composites fabrication}

After the seven incubation days, the resulting composites without fungal contamination were pressed with two different loads, group G1 ( $\mathrm{n}=6$ ) was loaded with 3922.66 $\mathrm{Pa}$ for two hours and group G2 $(\mathrm{n}=6)$ was pressed with $17651.97 \mathrm{~Pa}$ for two hours. The loads were selected observing the behavior of the straw to the load. The G1 represent the minimum compression in which the fibers maintain the form after unload. G2 was selected when the compression fills the inner gaps of the composites. These pressed materials were dried at $45^{\circ} \mathrm{C}$ for $72 \mathrm{~h}$. After drying, specimens were cut to approx. $3 \mathrm{~cm}$ width and $30 \mathrm{~cm}$ length avoiding empty spaces or hypoxic sites with poor mycelial growth (Fig.1). Posterior to cutting specimens, dimensions and weight were recorded. Specimens of each composite were submerged in water to evaluate water absorption after two periods, $2 \mathrm{~h}$ and $24 \mathrm{~h}$

\section{Mechanical testing}

A three-point bending test with a $288 \mathrm{~mm}$ span was performed using a Universal Test Machine INSTRON $3385 \mathrm{H}$ with the Bluebill II software, with a $5 \mathrm{kN}$ load cell (1 $\mathrm{N}$ resolution), a loading rate of $1.3 \mathrm{~mm} / \mathrm{min} \pm 25 \%$ and load control following ASTM D-143 standard test methods for small clear specimens, section 7 , for flexural strength and section 8 for parallel compression (Fig. 1). Stress-strain curves are showed on figure 2. Tests for expanded polystyrene specimens were also made following the ASTM C 578-04 standards in order to compare results. A Tukey test was carried out to compare results between groups and computed with SigmaPlot version 10.0.

\section{RESULTS AND DISCUSSION}

The results show differences between values obtained from G1 and G2 composites (Table 1). Mean values of Modulus of rupture (MOR) for the G1 composites are $0.11 \mathrm{MPa} \pm$ $0.04 \mathrm{MPa}$ and for $\mathrm{G} 2$ of $0.48 \mathrm{MPa} \pm 0.10 \mathrm{MPa}$ (Fig. 3c). 
The same trend was observed for maxim compressive strength $\left(f c_{\max }\right)$ in which $\mathrm{G} 2$ composites presented 0.235 $\mathrm{MPa} \pm 0.068 \mathrm{MPa}$ in comparison with $0.097 \mathrm{MPa} \pm 0.043$ MPa of G1. Regarding the modulus of elasticity (MOE), in G1 was $9 \mathrm{MPa} \pm 5.42 \mathrm{MPa}$, while in $\mathrm{G} 2$ was $26 \mathrm{MPa} \pm 5.19$ $\mathrm{MPa}$ (Fig. 2, 3). Statistical difference was found between G1 and $\mathrm{G} 2$ in all tests performed. Data obtained for expanded polystyrene was not statistically different for flexural strength and elastic modulus of G1 composites, showing that mechanical properties were very similar.
Balsa wood is a natural product that could be similar to mycelium composites. Data from Kotlarewski, Belleville, Gusamo, \& Ozarska, (2016) for balsa wood show that the differences in mechanical properties obtained for balsa wood are important and difficult to compare with the materials here developed. Only density values are similar to the obtained here, but the water absorption differs markedly.
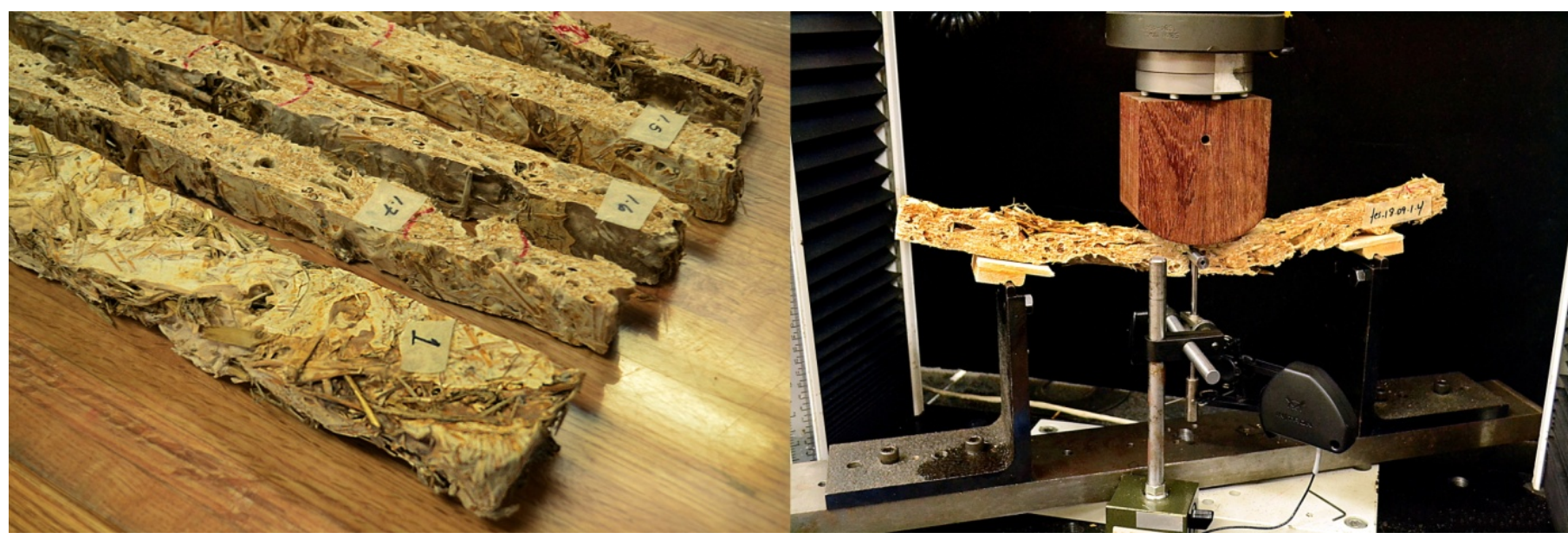

FIGURE1. Pictures of the mycelium composites obtained.
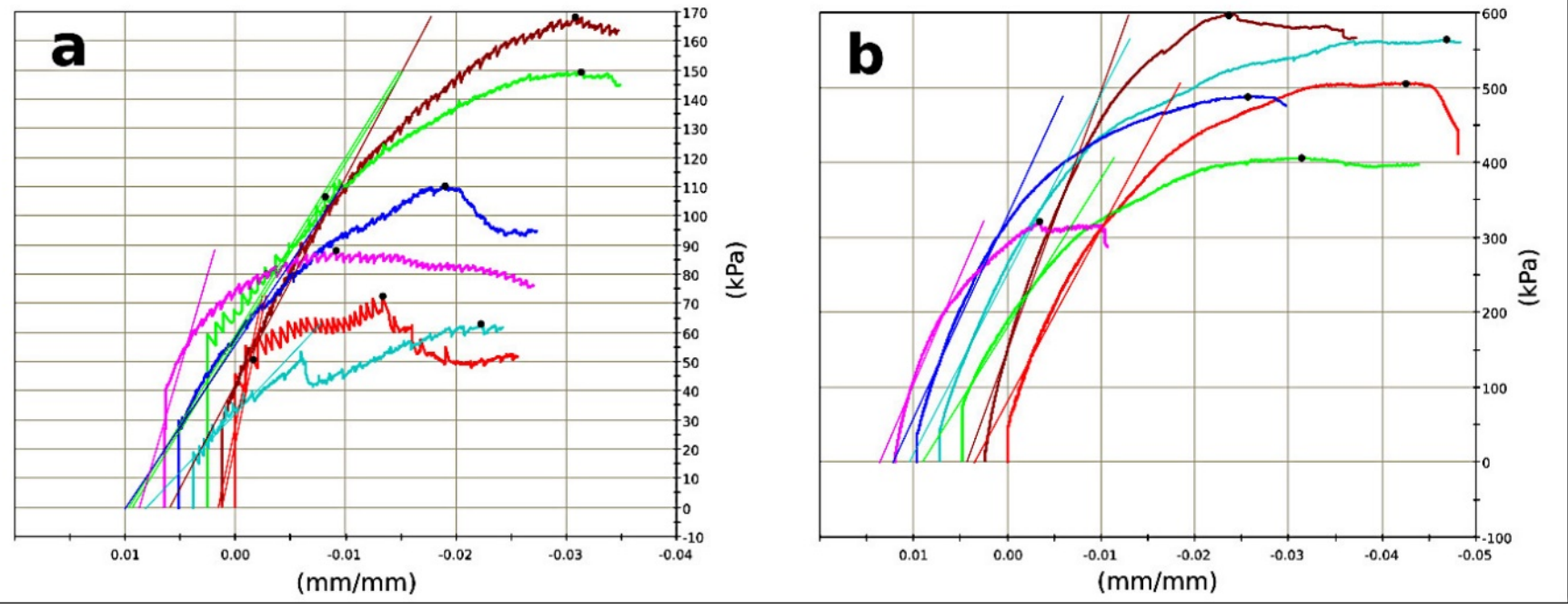

FIGURE 2. Stress-strain curves (MOR). a G1 tested specimens; b G2 tested specimens. 
TABLE 1. Results of the different tests for the G1 composites (pressed with $3.92 \mathrm{kPa}$ ), G2 composites (pressed $17.65 \mathrm{kPa}$ ), expanded polystyrene and balsa wood.

\begin{tabular}{|c|c|c|c|c|c|}
\hline Material & $\begin{array}{l}\text { Flexural strength } \\
\text { (MOR) } \\
(\mathrm{MPa})\end{array}$ & $\begin{array}{c}\text { Compressive } \\
\text { strength parallel to } \\
\text { grain }\left(f c_{\max }\right) \\
(\mathrm{MPa})\end{array}$ & $\begin{array}{l}\text { Modulus of } \\
\text { Elasticity (E) } \\
\text { (MPa) }\end{array}$ & $\begin{array}{l}\text { Density } \\
\left(\mathrm{kg} / \mathrm{m}^{3}\right)\end{array}$ & $\begin{array}{c}\text { Water absorption } \\
(\% 2 h / 24 h)\end{array}$ \\
\hline Gl composites & $0.11 \pm 0.04^{a}$ & $0.097 \pm 0.043^{a}$ & $9 \pm 5.42^{a}$ & $102 \pm 4^{a}$ & $\begin{array}{l}426.16 \pm 22.08 / \\
526.66 \pm 30.29^{a}\end{array}$ \\
\hline G2 composites & $0.48 \pm 0.10^{b}$ & $0.235 \pm 0.068^{b}$ & $26 \pm 5.19^{b}$ & $141 \pm 11^{\mathrm{b}}$ & $\begin{array}{l}592.5 \pm 46.66 / \\
710.5 \pm 59.30^{\mathrm{b}}\end{array}$ \\
\hline $\begin{array}{l}\text { Expanded } \\
\text { Polystyrene }\end{array}$ & $0.084 \pm 0.014^{a}$ & $\begin{array}{c}0.035 \text { (ASTM C } \\
578-04 \text { ) }\end{array}$ & $3.952 \pm 0.341^{a}$ & $10.83 \pm 0.55^{c}$ & $\begin{array}{c}4 \text { (ASTM C 578- } \\
04 \text { ) }\end{array}$ \\
\hline $\begin{array}{l}\text { Balsa Wood-light } \\
\text { density } \\
\text { (Kotlarewski et al. } \\
\text { 2016) }\end{array}$ & $9.83 \pm 1.72$ & $9.24 \pm 0.61$ & $1222.14 \pm 246.93$ & $80-120$ & $\begin{array}{l}31.16 \pm 7.67 / / \\
74.66 \pm 17.99\end{array}$ \\
\hline
\end{tabular}

According to its density, EPS type XI is compared. Letters indicate significant differences between groups.
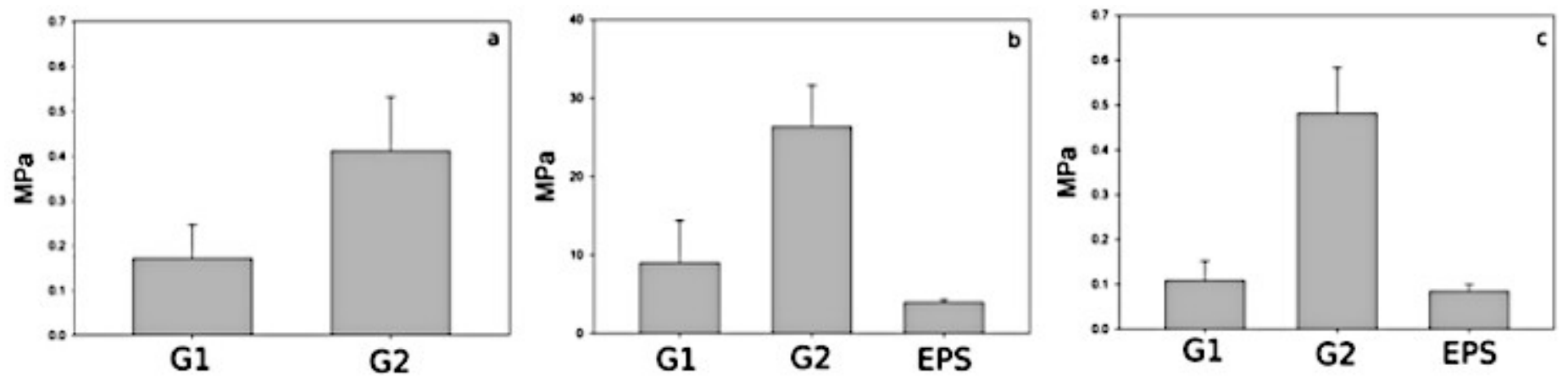

FIGURE 3. Values of performance obtained in this work. a) Compressive strength parallel to grain $\left(f c_{\max }\right)$ of mycelial composites. b) Modulus of elasticity values for mycelium composites and expanded polystyrene. c) Flexural strength (MOR) for mycelium composites and expanded polystyrene.

Comparing the results with those from other works, groups 1 and 2 evidence similarities in MOR values with Tudryn et al. (2017) and $f c_{\max }$ values with Roman-Ramos et al. (2014). Data for MOE in previous works (Table 2) differs in all cases. Density of the products is also diverse, showing that different fabrication protocols influence greatly the final properties. The composites of the G2 group exhibit higher properties in comparison with composites obtained by Holt et al. (2012) and López et al. (2016), the first developed with a mycelial matrix of Ganoderma sp., cotton gin waste as reinforcement and following different protocols of inoculation, that did not differ greatly between them.

The studied composites show characteristics comparable with materials used for fabrication of insulation panels. Previous works have showed the feasibility to substitute EPS in some applications. In this study, the mechanical performance of G2 composites showed higher characteristics than EPS, G1 composites are very similar. The water absorption by mycelial composites developed in this study like others is very high in comparison with 
synthetic materials, which could be an impediment for applications especially in food packaging. For ephemeral uses in a wide range of applications, mycelium composites could be used, distinctly in industrial sectors that uses foams that must have low density, low price and adequate mechanical performance like the automotive industry for some insulation parts. This kind of composites could be a good alternative for replacement EPS used in construction due to low fabrication price and green ecological footprint. In comparison to others works, data from Yang et al. (2017) shows excessive higher compressive strength in comparison with the values obtained here and others included in Table 2. The use in that work of a specific fungal species could be the reason and the combination of Irpex lacteus with other substrata would be interesting to assess.

\section{CONCLUSIONS}

As part of the fabrication protocols of mycelium composites, compression of materials after fungal colonization has shown to be a variable of importance as an indicator of more resistant composites. Higher loads could be tested but reaching a certain point a decrease in resistance is expected. Other characteristics that must be tested individually are the direction of fibers used as reinforcements and the size of these particles to generate better results. In this work, only the parallel to grain compressive strength was measured with a perpendicular load due to the heterogeneity of the obtained mycelium boards, a perpendicular to grain test would be suitable for more homogeneous samples with less than $25 \mathrm{~mm}$ width. Besides that, and taking into consideration the results of other works, the use of a specific fungal species must be carefully studied because a considerable percentage of the composite is represented by hyphal nets and this simple change modifies the entire structure.

\section{ACKNWOLEDGEMENTS}

We appreciate the funding received through the strategic project Instituto de Ecología, A.C. 20035/30890 and the support given by Conacyt (225382) to the Laboratorio de Presecuenciación, Red Biodiversidad y Sistemática, Inecol. Biol. D. Ramos and M.Sc. Bertha Pérez assisted us in the field and in some molecular procedures respectively.

TABLE 2. Mechanical properties of fungus-based materials published in literature.

\begin{tabular}{|c|c|c|c|c|c|}
\hline Reference & $\begin{array}{c}\text { Flexural strength } \\
\text { (MOR) } \\
(\mathrm{MPa})\end{array}$ & $\begin{array}{l}\text { Compressive strength } \\
\text { parallel to grain (fc } \max ) \\
\text { (MPa) }\end{array}$ & $\begin{array}{l}\text { Modulus of } \\
\text { Elasticity (E) } \\
\text { (MPa) }\end{array}$ & $\begin{array}{l}\text { Density } \\
\left(\mathrm{kg} / \mathrm{m}^{3}\right)\end{array}$ & $\begin{array}{l}\text { Water } \\
\text { absorption } \\
\text { (\%) }\end{array}$ \\
\hline López et al. (2016) & $0.01091 \pm 0.00441$ & $0.04172 \pm 0.01349$ & No data & $183.8 \pm 15.1$ & $268.4 \pm 80.4$ \\
\hline Holt et al. (2012) & $0.007-0.0261$ & $0.0011-0.0722$ & $0.1228-0.6745$ & $66.5-224$ & $10.8-48.0$ \\
\hline Yang et al. (2017) & No data & $0.35-0.57$ & $15-60$ & $240-265$ & No data \\
\hline Tudryn et al. (2017) & $0.3-1.3$ & No data & No data & No data & No data \\
\hline Ziegler et al. (2016) & No data & No data & $66.14-71.773$ & No data & 300 \\
\hline $\begin{array}{l}\text { Román-Ramos et al. } \\
\qquad(2014)\end{array}$ & No data & $0.054-0.139$ & No data & $450-550$ & No data \\
\hline Appels et al. (2019) & $0.05-0.86$ & No data & $2-97$ & $100-240$ & $43-508$ \\
\hline Silvermann, 2018 & No data & $0.124-0.34$ & No data & $\begin{array}{l}285.5- \\
353.9\end{array}$ & No data \\
\hline
\end{tabular}




\section{REFERENCES}

Appels, F. V., Camere, S., Montalti, M., Karana, E., Jansen, K. M., Dijksterhuis, J., Krijgsheld, P., \& Wösten, H.A. (2019). Fabrication factors influencing mechanical, moisture-and waterrelated properties of mycelium-based composites. Materials and Design, 161, 64-71. doi: 10.1016/j.matdes.2018.11.027

Bajwa, D., Holt, G., Bajwa, S., Duke, S., \& McIntyre, G. (2017). Enhancement of termite (Reticulitermes flavipes L.) resistance in mycelium reinforced biofiber-composites. Industrial Crops \& Products, 107, 420-426. doi: 10.1016/j.indcrop.2017.06.032

Camere, S., \& Karana, E. (2018). Fabricating materials from living organisms: An emerging design practice. Journal of Cleaner Production, 186, 570-584. doi: 10.1016/j.jclepro.2018.03.081

César, E. (2018). Caracterización y evaluación de sistemas hifales de macrobongos basidiomicetos de posible aplicación para el desarrollo de materiales biodegradables. Doctoral thesis, Instituto de Ecología A.C., Xalapa, Veracruz, México.

Chang, S., \& Miles, P. (1989). Edible mushrooms and their cultivation. Florida: CRC Press.

Chen, H., Yang, Y., \& Zhang, J. (2009). Biotechnological potential of cereal (wheat and rice) straw and bran residues. In N. Singh, P. Nigam \& A. Pandey (Eds.), Biotechnology for Agro-Industrial Residues Utilisation (pp. 328-339). Springer. doi: 10.1007/978-1-40209942-7_17

Chen, H. (2014). Biotechnology of lignocellulose: theory and practice. Dordrecht, Germany: Chemical Industry Press and Springer Science+Business Media.

Corner, E. (1932). The Fruit-body of Polystictus xanthopus. Annals of Botany, 46, 71-111. doi: 10.1093/oxfordjournals.aob.a090319

Dschida, W. (1997). Fungal cell wall production and utilization as a raw resource for textiles. US grant US5854056A.

Ecovative Design. (2020). Ecovative design main page. Recuperado de https://ecovativedesign.com

Haneef, M., Ceseracciu, L., Canale, C., Bayer, I., Heredia-Guerrero, J., \& Athanassiou A. (2017). Advanced materials from fungal mycelium: fabrication and tuning of physical properties. Science. Reports, 7, 41292; doi: 10.1038/srep41292

Holt, G., Mcintyre, G., Flagg, D., Bayer, E., Wanjura, J., \& Pelletier, M. (2012). Fungal mycelium and cotton plant materials in the manufacture of biodegradable molded packaging material: Evaluation study of select blends of cotton byproducts. Journal of Biobased Materials and Bioenergy, 6(4), 431-439. doi: 10.1166/jbmb.2012.1241
Jones, M., Huynh, T., Dekiwadia, C., Daver, F., \& John, S. (2017). Mycelium composites: a review of engineering characteristics and growth kinetics. Journal of Bionanoscience, 11(4), 241-257. doi: 10.1166/jbns. 2017.1440

Kotlarewski, N., Belleville, B., Gusamo, B., \& Ozarska B. (2016). Mechanical properties of Papua New Guinea Balsa wood. European Journal of Wood and Wood Products, 74(1), 83-89. doi: 10.1007/s00107-015-0983-0

Lelivelt, R. (2015). The mechanical possibilities of mycelium materials. Master thesis. University of Technology, Einhoven, Netherlands.

López, J., Méndez-González, J., Ruelas, X., \& Nájera J. (2016). Assessment of edible fungi and films bio-based material simulating expanded polystyrene. Materials and Manufacturing Processes, 31(8), 1085-1090. doi: 10.1080/10426914.2015.1070420

Netravali, A., \& Chabba S. (2003). Composites get greener. Materials today, 6(4), 22-29. doi: 10.1016/S1369-7021(03)00427-9

Pelletier, M., Holt, G., Wanjura, J., Bayer, E., \& McIntyre, G. (2013). An evaluation study of mycelium based acoustic absorbers grown on agricultural by-product substrates. Industrial Crops and Products, 51, 480-485. doi: 10.1016/j.indcrop.2013.09.008

Pelletier, M., Holt, G., Wanjura, J., Lara, A., Tapia-Carillo, A., McIntyre, G., \& Bayer, E. (2017). An evaluation study of pressurecompressed acoustic absorbers grown on agricultural byproducts. Industrial Crops and Products, 95, 342-347 doi: 10.1016/j.indcrop.2016.10.042

Petersen, R., Nicholl, D., \& Hughes, K. (1997). Mating systems of some putative polypore- agaric relatives. Plant Systematics and Evolution, 207(3), 135-158. doi: 10.1007/BF00984386

Román-Ramos, J., Luna-Molina, F., \& Bailón-Pérez, L. (2014). Encofrado perdido constituido por paja cohesionada con micelio como sustituto del poliestireno expandido. Informes de la Construcción, 66(EXTRA-1), m006 doi: 10.3989/ic.13.097

Senthilarasu, G. (2015). The lentinoid fungi (Lentinus and Panus) from Western Ghats, India. IMA Fungus, 6(1), 119-128. doi: 10.5598/imafungus.2015.06.01.06

Silverman, J. (2018). Development and testing of mycelium-based composite materials for shoe sole applications. Master thesis, University of Delaware, Newark, CA, USA.

Tudryn, G., Smith, L., Freitag, J., Bucinell, R., \& Schadler, L. (2017). Processing and morphology impacts on mechanical properties of fungal based biopolymer composites. Journal of polymers and the environment, 24, 1473-1483. doi: 10.1007/s10924-017-1047-9

Yang, Z., Zhang, F., Still, B., White, M., \& Amstislavski, P. (2017). Physical and mechanical properties of fungal mycelium-based 
biofoam. Journal of Materials in Civil Engineering, 29(7). doi: 10.1061/(ASCE)MT.1943-5533.0001866

Ziegler, A., Bajwa S., Holt, G., McIntyre, G., \& Bajwa, D. (2016). Evaluation of physico-mechanical properties of mycelium reinforced green biocomposites made from cellulosic fibers. Applied Engineering in Agriculture, 32(6), 931-938. doi: $10.13031 /$ aea.32.11830

Received: 24 September 2020

Accepted: 26 October 2020

Published: 30 December 2021
This paper must be cited as:

César, E., Montoya, L., Bárcenas-Pazos, M., OrdóñezCandelaria, V. R., \& Bandala, V. M. (2021). Performance of mycelium composites of Lentinus crinitus under two compression protocols. Madera y Bosques, 27(2), e2722047. doi: $10.21829 /$ myb.2021.2722047

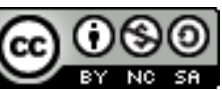

Madera y Bosques by Instituto de Ecología, A.C. is distributed under a Creative Commons Licence Attribution-NonCommercial-ShareAlike Internacional. 